\title{
PRZEGLĄD ZASTOSOWANIA ANTYCYKLICZNEGO BUFORA KAPITAŁOWEGO W EOG W REAKCJI NA WYBUCH PANDEMII WIRUSA SARS-COV-2
}

\author{
Piotr Petryka*
}

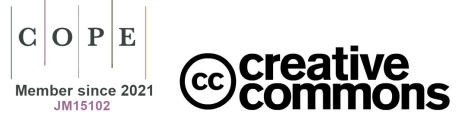

https://doi.org/10.18778/2391-6478.4.32.04

\section{REVIEW OF THE USE OF THE COUNTERCYCLICAL CAPITAL BUFFER IN THE EEA IN RESPONSE TO THE SARS-COV-2 VIRUS PANDEMIC OUTBREAK}

\section{Abstract}

The purpose of the article is to verify how the SARS-CoV-2 virus pandemic outbreak influenced the decisions to apply the countercyclical capital buffer in the EEA and whether, based on the experience gained so far in applying the countercyclical capital buffer in the EEA, it is possible to clearly distinguish between the models of its application.

Methodology used to achieve this, was to built the field of research and to perform a comparative analysis of macroeconomic data on the application of the above-mentioned instrument in the EEA during the COVID-19 pandemic crisis.

Results of the research are two methods and two variants of the application of the countercyclical capital buffer that were distinguished and named, indicating the benefits and challenges of using each of them. Moreover, the limited usefulness of the standardized and additional gap was confirmed in the light of the conducted research, available in the literature. The article concludes with recommendations for further research.

Keywords: Countercyclical capital buffer, economic crisis, macroprudential policy, COVID-19.

JEL Class: E58, G01, G21, G28.

\footnotetext{
* Magister, Uniwersytet Ekonomiczny w Katowicach, e-mail: piotr.petryka@edu.uekat.pl https://orcid.org/0000-0001-7815-6898
} 


\section{WSTĘP}

Po trzynastu latach od kryzysu finansowego 2007 r., gospodarkom światowym przyszło zmierzyć się z kolejnym kryzysem - gospodarczym, wywołanym globalną pandemią wirusa SARS-CoV-2. Zagadnieniami badawczymi, które zakreślają obszar badań niniejszego opracowania są pytania o stopień przygotowania systemów finansowych na nadejście nowego kryzysu gospodarczego, o odporność tych systemów na efekty szoku powstałego poza systemem finansowym ${ }^{1}$ oraz czy nadzór makroostrożnościowy wraz ze swoim instrumentarium, powołane do życia po kryzysie finansowym 2007 r. i w odpowiedzi na ryzyko powstania kolejnych kryzysów spełnia swoją rolę w toku trwającego kryzysu.

Jednym z głównych instrumentów makroostrożnościowych pozostaje antycykliczny bufor kapitałowy, mający w myśl swoich konstrukcyjnych założeń łagodzić cykliczne wahania poziomu kredytu w gospodarce ${ }^{2}$ i w efekcie ograniczyć cykliczne ryzyko systemowe. Zdarzenie poza systemem finansowym o wysokim stopniu nieprzewidywalności, jakim był jej wybuch, nie znalazło się w zasięgu możliwości predykcyjnych instrumentów makroostrożnościowych, w tym antycyklicznego bufora kapitałowego. W niniejszym opracowaniu nie rozważa się odporności tego instrumentu ex-ante na takie zdarzenia. Jednak reakcje o charakterze interwencyjnym względem gospodarek państw EOG na wybuch pandemii w zakresie stosowania antycyklicznego bufora kapitałowego dostarczają, niedostępne wcześniej na taką skalę, dane empiryczne o tym narzędziu ${ }^{3}$.

Niniejsze opracowanie ma na celu weryfikację, jak wybuch pandemii wirusa SARS-CoV-2 wpłynął na decyzje o stosowaniu antycyklicznego bufora kapitałowego w EOG oraz weryfikację hipotezy badawczej w brzmieniu: dotychczasowe

${ }^{1}$ W 2007 roku źródłem ryzyka systemowego była bańka spekulacyjna kredytów hipotecznych, a zatem zdarzenie z wnętrza systemu finansowego. W kryzysie z 2020 roku - nadal trwającym wirus SARS-CoV-2 był zdarzeniem szokowym, jednak nie sposób jeszcze mówić o kryzysie finansowym. A contrario definicjom ryzyka systemowego, w które literatura przedmiotu obfituje, system finansowy nie został zaburzony tak, by nie mógł funkcjonować lub jego dysfunkcje przynosiły negatywne konsekwencje sferze realnej. W niniejszym opracowaniu nie dokonuje się jednak próby aktualizacji definicji ryzyka systemowego na podstawie systematyki i przebiegu obecnie trwającego kryzysu gospodarczego.

${ }^{2} \mathrm{~W}$ przypadku zawiązania bufora w okresie nadmiernego wzrostu akcji kredytowej, banki zobowiązane zostają do utrzymania dodatkowego kapitału, co ma - zgodnie z konstrukcją bufora ograniczyć nadmierną akcję kredytową oraz zwiększyć odporność banków na potencjalne załamanie cyklu kredytowego poprzez zwiększenie bazy kapitałowej banków. W przypadku dekoniunktury i materializacji ryzyka kredytowego, utrzymywany dodatkowy kapitał zostaje uwolniony poprzez rozwiązanie bufora, a instytucje kredytujące powinny przeznaczyć uwolniony kapitał na kredytowanie gospodarki, co ma wesprzeć jej wyjście z recesji.

${ }^{3} \mathrm{Na}$ moment tworzenia niniejszego opracowania nie sposób jest określić, czy kryzys gospodarczy dobiegł końca i czy jego przebieg nie zaostrzy się, np. w kierunku kryzysu finansowego. Można jednak, a nawet należy stawiać pytania badawcze w kontekście wpływu obecnie trwającego kryzysu na systemy finansowe i gospodarkę realną. 
doświadczenia stosowania antycyklicznego bufora kapitałowego w EOG pozwalają wyraźnie rozróżnić modele jego stosowania.

Źródła, o które opiera się opracowanie to standaryzowane dane makroekonomiczne instytucji nadzoru makroostrożnościowego EOG oraz ich serwisy internetowe, akty normatywne prawa unijnego oraz krajowego, a także prace naukowe. Zbudowano obszar badania dla dokonania analizy porównawczej danych makroekonomicznych dotyczących stosowania ww. instrumentu w EOG w trakcie kryzysu wywołanego pandemią wirusa SARS-CoV-2 i dokonano ww. analizy. Sformułowano dodatkowe cele badawcze niniejszego opracowania - cel poznawczy i cele teoretyczne. Celem poznawczym jest zapoznanie się z doświadczeniami i motywami stosowania antycyklicznego bufora kapitałowego państw EOG. Nadrzędnym celem teoretycznym jest - w zależności od wyników weryfikacji hipotezy badawczej - rozróżnienie metod stosowania bufora antycyklicznego w EOG oraz sformułowanie wad i zalet stosowania tych metod. Dodatkowym celem teoretycznym - z uwagi na nieliczne, choć obszerne, dostępne w języku polskim prace przeglądowe traktujące o doświadczeniach stosowania bufora antycyklicznego przez inne niż Polska kraje - jest kontrybucja w literaturę przedmiotu niniejszym przeglądem zastosowania antycyklicznego bufora kapitałowego (dalej: $\mathrm{CCyB}$ ) w EOG w reakcji na wybuch pandemii wirusa SARS-CoV-2. Za datę wybuchu pandemii przyjęto roboczo dzień 1.03.2020 r.

Opracowanie składa się z 5 części. Rozpoczęto od przeglądu literatury przedmiotu i metodyki badań, a następnie przedstawiono ich wyniki. Dyskusja nad wynikami to część przedostatnia. Artykuł kończą wnioski i proponowane obszary dalszych badań.

\section{PRZEGLĄD LITERATURY}

Polityka makroostrożnościowa, obok monetarnej oraz fiskalnej jest konieczna dla zapewnienia stabilności finansowej, którą poważnie kontestuje trwający kryzys (Borio, 2020). Pandemia stanowi bezprecedensowe wyzwanie dla systemów finansowych (Rizwan i in., 2020) i jest całościowym urzeczywistnieniem ryzyka systemowego (Solarz i Waliszewski, 2020: 44-94), do minimalizacji którego dedykowany jest nadzór makroostrożnościowy wraz ze swoim instrumentarium (Pyka i in., 2019), w tym CCyB.

W stosunku do CCyB, będącego wiodącym ${ }^{4}$ instrumentem nadzoru makroostrożnościowego, od początku jego stosowania badacze krajów, które jako pierwsze implementowały w EOG do swoich porządków prawnych regulacje

${ }^{4}$ Wiodącym co do jego założeń. W praktyce, CCyB wykorzystywany jest przez mniejszą część krajów EOG, na co wskazuje się w dalszych częściach niniejszego opracowania. 
o CCyB, dyskutują o skuteczności założeń konstrukcyjnych CCyB, w szczególności bazylejskiej luki kredytowej (Pfeifer i Hodula, 2021; Giese i in., 2014) i sugerują uzupełnienie CCyB o inne wskaźniki, dopasowane do krajowych systemów.

W pierwszym etapie kryzysu pandemicznego $\mathrm{CCyB}^{5}$ odegrał kluczową rolę w absorbowaniu szoków wewnątrz sektorów finansowych i poza nimi. W tym zakresie pozytywnie ocenia się koncepcję utrzymywania niezerowego poziomu wskaźnika CCyB w warunkach neutralnych w kontekście gotowości do uwolnienia zgromadzonego w ten sposób kapitału w warunkach stresowych - niezależnie od występowania cyklicznego ryzyka systemowego (Dobrzańska, 2020).

Ustalanie CCyB na poziomie większym od $0 \% \mathrm{w}$ warunkach umiarkowanego ryzyka jako potencjalnie korzystną strategię wskazywały ex-ante kryzysu Europejska Rada ds. Ryzyka Systemowego (dalej również: ERRS) (ERRS, 2017: 36), a także Bazylejski Komitet Nadzoru Bankowego (dalej również: BKNB) (BIS, 2017: 18), który w przeglądzie jurysdykcji z niezerową stawką CCyB uwypuklił różnice w uzasadnieniu aktywowania $\mathrm{CCyB}$, zestawiając kraje aktywujące $\mathrm{CCyB}$ głównie na podstawie rosnącej luki kredytowej z krajem (Wielka Brytania) aktywującym CCyB w warunkach neutralnych. Badacze natomiast wskazywali na konieczność zaostrzenia polityki makroostrożnościowej w zakresie stosowania CCyB jako konkluzje badań wykorzystujących modele DSGE do oceny efektów i optymalizacji ,bazylejskich” regulacji wymogów kapitałowych banków (Rubio i Yao, 2020; Rubio i Carrasco-Gallego, 2016).

Przyjęcie wskaźników identyfikujących bieżącą fazę cyklu finansowego za podstawę instrumentariów organów makroostrożnościowych wskazują również Pfeifer i Hodula (2021) jako dominującą praktykę określania CCyB, podkreślając istotność uzupełnienia takich praktyk systemami wczesnego ostrzegania skalibrowanymi do partykularnych gospodarek. Te z kolei, różnią się długościami cyklów finansowych i to podkreślając, Reigl i Uuskula (2021) sugerują - względem metody bazylejskiej - cztery alternatywne metody pomiaru dodatkowej luki kredytowej, potwierdzając przy tym nieadekwatność metody bazylejskiej dla krajów o krótkich, dostępnych szeregach czasowych danych stanowiących podstawę wyliczania luki kredytowej. Zatem wiarygodność szacunków luki kredytowej jest w znacznym stopniu zależna od długości danych dostępnych do ich obliczenia, co potwierdzają również badacze spoza EOG (Deryugina i in., 2020). W kontekście luki kredytowej jako głównej podstawy CCyB wskazuje się, że wzrost kredytów do PKB nie musi wiązać się ze wzrastającym ryzykiem wystąpienia kryzysu, a może bywać fałszywym sygnałem dla nadzorów do nałożenia dodatkowych wymogów kapitałowych na banki (Barrell i in., 2020).

${ }^{5} \mathrm{~W}$ krajach, w których był stosowany. 
$\mathrm{Na}$ podstawie analizy porównawczej danych empirycznych stosowania CCyB w UE w latach 2014-2018 zaobserwowano, kiedy kraje UE nie podążały za standardowymi wskaźnikami do kalibracji CCyB jak standaryzowana luka kredytowa $^{6}$ czy dodatkowa luka kredytowa ${ }^{7}$ przy ustalaniu CCyB (Dobrzańska i Kurowski, 2019). Ponadto, wskazano tam na ograniczoną użyteczność standaryzowanej i dodatkowej luki kredytowej, podkreślając doświadczenia krajów poddanych analizie w stosowaniu dodatkowych zmiennych połączonych z oceną ekspercką.

Obszerną krytykę użyteczności metody bazylejskiej stosowania CCyB należy zestawić z brakiem ograniczeń do stosowania innych wskaźników, co wynika bezpośrednio z podstaw prawnych stosowania CCyB, ponieważ metoda ta traktowana jest jako wstępny punkt odniesienia, który należy uzupełnić informacjami z innych wskaźników i modeli (Galan i Mencia, 2021).

\section{METODYKA BADAŃ}

W niniejszym opracowaniu przyjęto że CCyB stosowany jest głównie przez dwa zbiory krajów: 27 członków BKNB oraz 31 członków EOG ${ }^{8}$. By zwiększyć stopień porównywalności ww. obserwacji, zdecydowano o wyborze EOG spośród przedstawionych zbiorów. Przyjęto założenie, że wspólny system nadzoru makroostrożnościowego oraz m.in. wspólnota rynków kapitałowych EOG wpłynie pozytywnie na stopień porównywalności obserwacji.

W zakresie danych empirycznych o stosowaniu CCyB w EOG bazowano na danych standaryzowanych udostępnionych przez ERRS ${ }^{9}$. Uzupełniająco, opierano się na danych krajowych organów nadzoru makroostrożnościowego EOG ${ }^{10}$ w języku angielskim.

${ }^{6}$ Rozumiana jako odchylenie wskaźnika kredytów dla prywatnego sektora niefinansowego do PKB od długoterminowego trendu, wyodrębnionego za pomocą rekursywnego filtra Hodricka-Prescotta z parametrem wygładzania $\lambda=400000$ (Dz.Urz. UE C 293/1 z dnia 02.09.2014).

${ }^{7}$ Rozumiana podobnie jak standaryzowana luka kredytowa, lecz z parametrami dopasowanymi w szczególności do długości cyklu finansowego danego państwa, z uwzględnieniem empirycznej analizy danych odpowiednich dla danego państwa (Dz.Urz. UE C 293/1 z dnia 02.09.2014).

${ }^{8}$ Od 31 grudnia 2020 r. 30 członków, bez Wielkiej Brytanii.

${ }^{9}$ ERRS dysponuje danymi 30 krajów dotyczącymi CCyB, publikuje je w ustandaryzowany sposób pozwalający na dokonanie podstawowych analiz porównawczych w zakresie stosowania przez te kraje antycyklicznego bufora kapitałowego. Badania w ramach niniejszego opracowania zostały oparte o ustandaryzowane dane udostępnione przez ERRS za okres od 12 grudnia 2013 r. do 7 czerwca 2021 r. (ERRS, 2021).

${ }^{10}$ Dla czytelności wywodu w kontekście gromadzenia danych dla celów niniejszego opracowania, dane Wielkiej Brytanii - z uwagi na większy udział czasowy Wielkiej Brytanii jako członek EOG niż udział czasowy bez jej członkostwa w EOG - przedstawia się jako część zbioru danych krajowych organów nadzoru makroostrożnościowego EOG, chyba że poszczególne części opracowania stanowią inaczej i rozróżniają te zbiory. 
Zakres czasowy badania obejmuje okres od 01.03.2020 do 07.06.2021. Dla celów porównawczych ${ }^{11} \mathrm{i}$ z uwagi na odstępy czasowe pomiędzy publikacją danych nadzorów makroostrożnościowych oraz na odstępy czasowe pomiędzy datami publikacji rekordów danych standaryzowanych ERRS przyjęto dodatkowe dwa podokresy:

- 01.03.2020 do 30.04.2020 (dalej również: okres „,pierwszych reakcji”);

- 01.05.2020 do 07.06.2021 ${ }^{13}$ (dalej również: okres „ostatnich danych”).

Dyrektywa CRD V (Dz.Urz. UE L 150 z dnia 07.06.2019, s. 253, z późn. zm.) oraz Rozporządzenie CRR II (Dz.Urz. UE L 150 z dnia 07.06.2019, s. 1, z późn. zm.) stanowiące wyjściowe normy prawa unijnego dla instrumentarium makroostrożnościowego, na mocy Porozumienia EOG (Dz.Urz. UE L z 1994 r. nr 1, s. 3 z późn. zm.) obowiązują również po transpozycji do ustawodawstwa krajowego lub w ramach bezpośrednio stosowania, w krajach EOG niebędących krajami UE (Dz.U. 2004, nr 90, poz. 864/2 z późn. zm., art. 217). W konsekwencji, poza 27 krajami UE, 4 kraje EOG zobowiązały się do stosowania instrumentów nadzoru makroostrożnościowego, w tym antycyklicznego bufora kapitałowego, w wyniku odpowiedniego zastosowania norm Dyrektywy CRD V oraz Rozporządzenia CRR II. Krajami tymi są: Islandia, Lichtenstein, Norwegia oraz do 31.12.2020 r. ${ }^{14}$ pozostawała Wielka Brytania ${ }^{15}$.

${ }^{11} \mathrm{~W}$ dyskusji nad wynikami badań, zestawieniach porównawczych, wnioskach i rekomendacjach oraz w samej analizie porównawczej bazowano na danych jednorodnych co do sposobu ich uzyskiwania lub wyliczenia, np. wskaźnik kredyt do PKB, wskaźnik standaryzowanej luki kredytowej. Dodatkowa luka kredytowa, z uwagi na jej niejednorodny charakter (kraje EOG mogą wyznaczać dodatkową lukę kredytową skalibrowaną dla cyklów finansowych odpowiednich dla danego kraju) nie była podstawą analizy porównawczej.

${ }^{12}$ Należy zwrócić uwagę, że daty ogłoszenia wskaźnika z okresu „pierwszych reakcji” dla większości krajów nie są datami co-kwartalnymi (zob. tabela 1). Jak wskazują standaryzowane dane ERRS w zakresie uzasadnienia poszczególnych decyzji, te poza-harmonogramowe działania w zakresie bufora antycyklicznego to najczęściej część pakietu środków mających na celu złagodzenie negatywnych skutków dla obywateli i przedsiębiorstw wynikających z ograniczeń związanych $\mathrm{z}$ pandemią wirusa SARS-CoV-2.

${ }^{13}$ 07.06.2021 to data ostatniej aktualizacji standaryzowanych danych ERRS w stanie na dzień niniejszego opracowania, tj. 07.06.2021.

14 Wielka Brytania pozostawała członkiem EOG w ramach okresu tranzytowego od 31.01.2020 do 31.12.2020. Po tym okresie Wielka Brytania jest uznana w świetle art. 126 Porozumienia EOG w zw. z art. 126 Umowy o wystąpieniu Zjednoczonego Królestwa Wielkiej Brytanii i Irlandii Północnej z UE i Europejskiej Wspólnoty Energii Atomowej (Dz.U. UE. C. z 2019 r., s. 144) za kraj trzeci.

${ }^{15} \mathrm{~W}$ świetle wystąpienia Wielkiej Brytanii z UE warto zaznaczyć, że Wielka Brytania kontynuuje stosowanie antycyklicznego bufora kapitałowego, a za publikacje danych z nim związanych odpowiada nadal Komitet ds. Polityki Stabilności Finansowej (Financial Policy Committee, FPC), tj. właściwy organ nadzoru makroostrożnościowego (BOE, 2021a). 


\section{WYNIKI BADAŃ}

Wybrane dane porównawcze stosowania CCyB przez 14 krajów EOG, które aktywowały historycznie CCyB, za okres od 01.03.2020 do 07.06.2021 (z podokresami ,pierwszych reakcji” oraz „ostatnich danych”) przedstawiono w tabeli 1 oraz tabeli 2.

Tabela 1. Wybrane dane porównawcze stosowania CCyB w EOG za okres od 01.03.2020 do 07.06.2021 - przebieg ustalania wskaźnika CCyB

\begin{tabular}{|c|c|c|c|c|c|c|c|c|}
\hline \multirow[b]{2}{*}{ Kraj } & \multirow[b]{2}{*}{$\begin{array}{c}\text { Pre_C19 } \\
{[\%]}\end{array}$} & \multirow[b]{2}{*}{$\begin{array}{c}\text { Data ogłosze- } \\
\text { nia CCyB = } \\
\text { data reakcji }\end{array}$} & \multirow[b]{2}{*}{$\begin{array}{c}\text { Post_C19 } \\
{[\%]}\end{array}$} & \multirow[b]{2}{*}{\begin{tabular}{|c} 
B \\
Standary- \\
zowana \\
luka kre- \\
dytowa \\
w dacie \\
„pierw- \\
szych re- \\
akcji” (A) \\
[\%]
\end{tabular}} & \multirow[b]{2}{*}{$\begin{array}{c}\text { CCyB na } \\
\text { podstawie } \\
\text { standary- } \\
\text { zowanej } \\
\text { luki kre- } \\
\text { dytowej } \\
\text { (B) w da- } \\
\text { cie pierw- } \\
\text { szych re- } \\
\text { akcji" (A) } \\
\text { [\%] }\end{array}$} & $\mathrm{C}$ & \multirow[b]{2}{*}{$\begin{array}{c}\text { CCyB na } \\
\text { podstawie } \\
\text { standaryzo- } \\
\text { wanej luki } \\
\text { kredytowej } \\
\text { (C) w dacie } \\
\text { "ostatnich } \\
\text { danych" } \\
{[\%]}\end{array}$} & \multirow[b]{2}{*}{$\begin{array}{c}\text { Aktualny } \\
\text { CCyB } \\
(07.06 . \\
2021) \\
{[\%]}\end{array}$} \\
\hline & & & & & & $\begin{array}{c}\text { Standary- } \\
\text { zowana } \\
\text { luka kre- } \\
\text { dytowa } \\
\text { w dacie } \\
\text { "ostatnich } \\
\text { danych } \\
{[\%] "}\end{array}$ & & \\
\hline $\mathrm{BE}$ & 0,50 & 27.03.2020 & 0 & $-18,4$ & 0 & $-7,5$ & 0 & 0,0 \\
\hline BG & 1,50 & 19.03.2020 & 0,50 & $-38,9$ & 0 & $-29,8$ & 0 & 0,5 \\
\hline $\mathrm{CZ}$ & 2 & 26.03.2020 & 1 & $-3,4$ & 0 & $-1,6$ & 0 & 1,0 \\
\hline DK & 2 & 12.03 .2020 & 0 & $-31,73$ & 0 & $-19,89$ & 0 & 0,0 \\
\hline FR & 0,5 & 01.04 .2020 & 0 & 3,2 & 0,5 & 15,3 & 2,5 & 0,0 \\
\hline DE & 0,25 & 31.03 .2020 & 0 & 6,02 & 1,26 & 11,71 & 2,5 & 0,0 \\
\hline IS & 2 & 18.03 .2020 & 0 & $-44,2$ & 0 & $-19,5$ & 0 & 0,0 \\
\hline IE & 1 & 01.04 .2020 & 0 & -79 & 0 & -94 & 0 & 0,0 \\
\hline LT & 1 & 31.03 .2020 & 0 & $-9,1$ & 0 & $-11,3$ & 0 & 0,0 \\
\hline $\mathrm{LU}$ & 0,50 & 24.04 .2020 & 0,50 & $-54,26$ & 0 & $-49,81$ & 0 & 0,5 \\
\hline NO & 2,50 & 13.03 .2020 & 1 & $-5,11$ & 0 & 1,85 & 0 & 1,0 \\
\hline SK & 2 & 30.04 .2020 & 1,5 & $-3,93$ & 0 & 1,15 & 0 & 1,0 \\
\hline SE & 2,50 & 16.03 .2020 & 0 & 2,6 & 0,18 & 7,5 & 1,7 & 0,0 \\
\hline UK & 2 & 11.03 .2020 & 0 & $-11,9$ & 0 & 2,3 & 0,09 & 0,0 \\
\hline
\end{tabular}

Oznaczenia kolumn: Pre_C19 = wysokość ostatniego ogłoszonego CCyB przed pandemią; Post_C19 = wysokość ogłoszonego CCyB w reakcji na pandemię.

Źródło: opracowanie własne na podstawie: ERRS, 2021; BAFIN, 2021a; BNB, 2021; BOE, 2021b; CBI, 2021; CNB, 2021b; Finansinspektionen, 2021; HCSF, 2021; NBB, 2021; NBS, 2021; Regjeringen, 2021. 
Tabela 2. Wybrane dane porównawcze stosowania CCyB w EOG za okres od 01.03.2020 do 07.06.2021 (EOG) i do 9.03.2021 (UK) - standaryzowana luka kredytowa, dodatkowa luka kredytowa

\begin{tabular}{|c|c|c|c|c|c|c|c|c|}
\hline & & A & B & $\mathrm{C}$ & $\mathrm{C}-\mathrm{B}$ & D & E & $E-D$ \\
\hline Kraj & $\begin{array}{l}\text { Data } \\
\text { pierw- } \\
\text { szej ak- } \\
\text { tywacji } \\
\text { CCyB }\end{array}$ & $\begin{array}{c}\text { Data } \\
\text { ogłosze- } \\
\text { nia } \\
\text { CCyB = } \\
\text { data re- } \\
\text { akcji }\end{array}$ & $\begin{array}{c}\text { Standary- } \\
\text { zowana } \\
\text { luka kre- } \\
\text { dytowa } \\
\text { w dacie } \\
\text { reakcji } \\
\text { (A) } \\
{[\%]}\end{array}$ & $\begin{array}{c}\text { Standary- } \\
\text { zowana } \\
\text { luka kre- } \\
\text { dytowa } \\
\text { w dacie } \\
\text { ostatnich } \\
\text { danych } \\
{[\%]}\end{array}$ & $\begin{array}{c}\text { Skokowa } \\
\text { dynamika } \\
\text { standaryzo- } \\
\text { wanej luki } \\
\text { kredytowej } \\
\text { w badanym } \\
\text { okresie } \\
\text { (C) - (B) }\end{array}$ & $\begin{array}{c}\text { Wskaźnik } \\
\text { dodatkowej } \\
\text { luki kredy- } \\
\text { towej w da- } \\
\text { cie „pierw- } \\
\text { szych reak- } \\
\text { cji” (A) } \\
\text { [\%] }\end{array}$ & $\begin{array}{c}\text { Wskaźnik } \\
\text { dodatkowej } \\
\text { luki kredy- } \\
\text { towej w da- } \\
\text { cie „ostat- } \\
\text { nich da- } \\
\text { nych” } \\
\text { [\%] }\end{array}$ & $\begin{array}{c}\text { Skokowa } \\
\text { dynamika } \\
\text { dodatkowej } \\
\text { luki kredy- } \\
\text { towej w ba- } \\
\text { danym okre- } \\
\text { sie } \\
\text { (E) - (D) }\end{array}$ \\
\hline BE & $\begin{array}{c}28.06 . \\
2019 \\
\end{array}$ & $\begin{array}{c}27.03 . \\
2020 \\
\end{array}$ & $-18,4$ & $-7,5$ & 10,9 p.p. & 2,1 & 6,2 & 4,1 p.p. \\
\hline BG & $\begin{array}{c}26.09 . \\
2018 \\
\end{array}$ & $\begin{array}{c}19.03 . \\
2020\end{array}$ & $-38,9$ & $-29,8$ & 9,1 p.p. & $\mathrm{b} / \mathrm{d}$ & $\mathrm{b} / \mathrm{d}$ & $\mathrm{b} / \mathrm{d}$ \\
\hline $\mathrm{CZ}$ & $\begin{array}{c}18.12 . \\
2015\end{array}$ & $\begin{array}{c}26.03 . \\
2020\end{array}$ & $-3,4$ & $-1,6$ & 1,8 p.p. & 0,9 & 3,2 & 2,3 p.p. \\
\hline DK & $\begin{array}{c}14.03 . \\
2018\end{array}$ & $\begin{array}{c}12.03 . \\
2020\end{array}$ & $-31,73$ & $-19,89$ & 11,84 p.p. & $\mathrm{b} / \mathrm{d}$ & $\mathrm{b} / \mathrm{d}$ & $b / d$ \\
\hline FR & $\begin{array}{c}01.07 . \\
2018\end{array}$ & $\begin{array}{c}01.04 . \\
2020\end{array}$ & 3,2 & 15,3 & 12,1 p.p. & 2,8 & 12,9 & 10,1 p.p. \\
\hline $\mathrm{DE}$ & $\begin{array}{c}28.06 . \\
2019\end{array}$ & $\begin{array}{c}31.03 . \\
2020\end{array}$ & 6,02 & 11,71 & 5,69 p.p. & 1,65 & 6,84 & 5,19 p.p. \\
\hline IS & $\begin{array}{c}01.03 . \\
2016\end{array}$ & $\begin{array}{c}18.03 . \\
2020\end{array}$ & $-44,2$ & $-19,5$ & 24,7 p.p. & $\mathrm{b} / \mathrm{d}$ & $\mathrm{b} / \mathrm{d}$ & $b / d$ \\
\hline IE & $\begin{array}{c}05.07 . \\
2018 \\
\end{array}$ & $\begin{array}{c}01.04 . \\
2020\end{array}$ & -79 & -94 & -15 p.p. & -1 & $-1,6$ & $-0,6$ p.p. \\
\hline LT & $\begin{array}{c}21.12 . \\
2017 \\
\end{array}$ & $\begin{array}{c}31.03 . \\
2020 \\
\end{array}$ & $-9,1$ & $-11,3$ & $-2,2$ p.p. & $-2,9$ & $-4,8$ & $-1,9$ p.p. \\
\hline $\mathrm{LU}$ & $\begin{array}{c}31.12 . \\
2018\end{array}$ & $\begin{array}{c}24.04 . \\
2020\end{array}$ & $-54,26$ & $-49,81$ & 4,45 p.p. & $-0,63$ & 3,7 & 4,33 p.p. \\
\hline NO & $\begin{array}{c}12.12 . \\
2013\end{array}$ & $\begin{array}{c}13.03 . \\
2020\end{array}$ & $-5,11$ & 1,85 & 6,96 p.p. & 2,04 & 7,96 & 5,92 p.p. \\
\hline SK & $\begin{array}{c}29.07 . \\
2016\end{array}$ & $\begin{array}{c}30.04 \\
2020\end{array}$ & $-3,93$ & 1,15 & 5,08 p.p. & $\mathrm{b} / \mathrm{d}$ & $\mathrm{b} / \mathrm{d}$ & $\mathrm{b} / \mathrm{d}$ \\
\hline SE & $\begin{array}{c}10.09 \\
2014\end{array}$ & $\begin{array}{c}16.03 . \\
2020\end{array}$ & 2,6 & 7,5 & 4,9 p.p. & $\mathrm{b} / \mathrm{d}$ & $\mathrm{b} / \mathrm{d}$ & $\mathrm{b} / \mathrm{d}$ \\
\hline UK & $\begin{array}{c}29.03 . \\
2016\end{array}$ & $\begin{array}{c}11.03 . \\
2020\end{array}$ & $-11,9$ & 2,3 & 14,2 p.p. & $\mathrm{b} / \mathrm{d}$ & $\mathrm{b} / \mathrm{d}$ & $\mathrm{b} / \mathrm{d}$ \\
\hline
\end{tabular}

Źródło: opracowanie własne na podstawie: ERRS, 2021; BAFIN, 2021a; BNB, 2021; BOE, 2021b; CBI, 2021; CNB, 2021b; Finansinspektionen, 2021; HCSF, 2021; NBB, 2021; NBS, 2021; Regjeringen, 2021. 
Na dzień 07.06.2021 tylko pięć krajów spośród 30 krajów EOG oraz Wielkiej Brytanii posiadało aktywowany bufor antycykliczny. Krajami tymi były: Norwegia, Czechy, Słowacja, Bułgaria oraz Luksemburg. Wymienione kraje pozostawały w grupie 14 krajów badanego obszaru ${ }^{16}$, które historycznie zdecydowały się aktywować CCyB. Wskazywało to na ograniczony, dostępny obszar badań nad doświadczeniami stosowania CCyB w EOG i zdecydowano się zawęzić analizę porównawczą do tych krajów.

W ramach próby ww. 14 krajów z historią stosowania bufora antycyklicznego, w okresie ,pierwszych reakcji” wszystkie poza Luksemburgiem zniosły, obniżyły wysokość lub wstrzymały podwyżkę wysokości obowiązującego wskaźnika CCyB. We wskazanym okresie, z 13 krajów korelujących swoje decyzje z pandemią wirusa SARS-CoV-2, 9 krajów obniżyło wskaźnik bufora do $0 \%$, a tylko 4 kraje pozostawiły dodatni wskaźnik po jego obniżeniu (Norwegia, Czechy, Słowacja i Bułgaria).

Skokowa dynamika ${ }^{17}$ wskaźnika standaryzowanej luki kredytowej wskazywała na wzrost standaryzowanej luki kredytowej w badanym okresie dla 12 z próby 14 krajów. Dla 6 spośród 8 krajów, dla których z tej samej próby dostępne są standaryzowane dane o dodatkowej luce kredytowej, odnotowano wzrost dodatkowej luki. Dla dwóch krajów (Litwa, Irlandia) odnotowano spadek zarówno standaryzowanej luki kredytowej, jak i dodatkowej luki kredytowej.

\section{DYSKUSJA NAD WYNIKAMI BADAŃ}

\subsection{Doświadczenia wyróżnionych krajów częściowo uwalniających kapitał z CCyB}

Warto zwrócić uwagę na tło podejmowania decyzji 4 krajów, które nie obniżyły wskaźnika bufora do poziomu $0 \%$. Czechy zdecydowały o stopniowym uwalnianiu bufora antycyklicznego (CNB, 2020a), ogłaszając obniżkę o 1 punkt procentowy z poziomu 2 na $1 \%$ (26.03.2020). Kwartał później (18.06.2020) ogłoszono kolejną obniżkę o 0,5 p.p. z 1 na $0,5 \%{ }^{18}$. Postanowienie z $27.05 .2021 \mathrm{w}$ sprawie

1614 krajów spośród 30 to w przybliżeniu zaledwie 46,(6)\% populacji krajów EOG. W grupie tych 14 krajów 11 krajów to kraje UE, 2 kraje, które nie należały do UE, przy czym należały do EOG (Islandia, Norwegia) oraz Wielka Brytania, uwzględniona ze względów historycznych w badanej grupie.

${ }^{17} \mathrm{~W}$ ujęciu niniejszych badań skok roczny rozumiany jest jako różnica wysokości wskaźnika standaryzowanej luki kredytowej w dacie „ostatnich danych” a wysokością wskaźnika standaryzowanej luki kredytowej w dacie ,pierwszych reakcji”.

${ }_{18}$ Poziom ten potwierdzono w kolejnych trzech ogłoszeniach - 27.08.2020 (CNB, 2020b), 26.11.2020 (CNB, 2020c) oraz 04.03.2021 (CNB, 2021a), argumentując pozostawienie wskaźnika $\mathrm{CCyB}$ na poziomie dodatnim jako zapewnienie pola do dalszego łagodzenia wymogu kapitałowego w przypadku wzrostu wag ryzyka dla portfeli kredytowych lub strat kredytowych oraz spadku wol- 
ustalenia wskaźnika bufora antycyklicznego dla Czech nr II/2021 (CNB, 2021b) wskazuje zmianę trendu z utrzymywania wskaźnika na poziomie $0,5 \% \mathrm{w}$ kierunku stopniowego, powrotnego budowania kapitałów w ramach $\mathrm{CCyB}$ opierając się przede wszystkim na zaobserwowanym rosnącym tempie wzrostu kredytów dla gospodarstw domowych na zakup mieszkania ${ }^{19}$. Ogłoszony w ten sposób wskaźnik na poziomie $1 \%{ }^{20}$ może podlegać dalszym zmianom ${ }^{21}$.

Norwegia, która spośród Państw EOG najwcześniej zaczęła stosować CCyB, obniżyła jego poziom o 1,5 p.p. z poziomu 2,5 do poziomu $1,0 \%{ }^{22}(13.03 .2020)$. W okresie „pierwszych reakcji” nie spodziewała się też ogłosić zwiększenia wskaźnika bufora najwcześniej do I kwartału 2021 r. (Regjeringen, 2020a). Konsekwentnie, w ramach kolejnych ogłoszeń wysokości wskaźnika - 18.06.2020 (Regjeringen, 2020b) a 24.09.2020 (Regjeringen, 2020c), 17.12.2020 (Regjeringen, 2020d) oraz 18.03.2021 (Regjeringen, 2021) - potwierdzono utrzymanie jego poziomu na $1 \% 23$.

W okresie ,pierwszych reakcji” ${ }^{24}$ słowacki sektor bankowy utrzymuje wystarczający poziom kapitału, powyżej minimalnych wymogów kapitałowych i nie

nych zdolności kredytowych, z drugiej strony nie decydując się na dalsze jego obniżanie (do poziomu $0,0 \%)$ z uwagi na wysokie nadwyżki kapitałowe w sektorze bankowym i utrzymujący się wzrost kredytów.

${ }^{19} \mathrm{~W}$ połączeniu ze zwiększoną oceną ryzyka takich pozycji w bilansach banków z uwagi na pogorszenie aktywności gospodarczej w wyniku pandemii, potwierdza to konieczność ponownego tworzenia bazy kapitałowej banków z użyciem CCyB.

${ }^{20}$ Ogłoszony wskaźnik w 2021 r., powinien być odniesiony na kapitały od 01.07.2022.

${ }^{21} \mathrm{~W}$ przypadku kontynuacji szybkiego wzrostu kredytów w sektorze gospodarstw domowych, ponownego dodatniego wzrostu kredytów dla przedsiębiorstw oraz szybszego podejmowania ryzyka w bilansie sektora bankowego, czeski nadzór makroostrożnościowy jest gotowy do dalszego podwyższania wskaźnika CCyB. Natomiast w przypadku ponownego pogorszenia się sytuacji gospodarczej na skutek np. kolejnej fali pandemii, czeski nadzór makroostrożnościowy będzie gotowy natychmiast i całkowicie uwolnić bufor, aby wesprzeć zdolność banków do udzielania kredytów przedsiębiorstwom niefinansowym i gospodarstwa domowe bez przerwy. Decydującym sygnałem do takiego kroku byłoby znaczne pogorszenie sytuacji gospodarczej, materializacja wcześniej akceptowanego ryzyka cyklicznego poprzez straty kredytowe oraz wzrost wag ryzyka dla portfeli kredytowych.

${ }^{22} \mathrm{~W}$ przypadku Norwegii jest to poziom wyjściowy, gdyż od pierwszego ogłoszenia wysokości wskaźnika w grudniu 2013 roku na tym poziomie, Norwegia nie ogłaszała go w wysokości niższej niż 1,0\%.

${ }^{23}$ Ostatnie z ogłoszeń referuje do rosnącej ceny nieruchomości mieszkaniowych, co obserwuje się od II kwartału 2020 r. i utrzymującej się wskutek spowolnienia gospodarczego niepewności związanej ze stratami kredytowymi dla banków, pomimo dobrego aktualnie przygotowania banków do absorbowania potencjalnych strat, przy jednoczesnym utrzymaniu poziomu akcji kredytowej. $\mathrm{Z}$ tego względu, norweski nadzór makroostrożnościowy zaleci stopniowe zwiększanie bufora w ciągu 2021 r., potencjalnie do poziomu 2,5\%, tj. poziomu sprzed 13.03.2020.

${ }^{24}$ Wskazywano wówczas na reaktywne względem kryzysu działania Europejskiego Banku Centralnego w zakresie tymczasowego obniżenia wymogów kapitałowych w przypadku instrumentów innych niż kapitał podstawowy TIER 1, przyczyniające się do możliwości elastycznego reagowania na możliwe wstrząsy w systemie finansowym. 
otrzymuje sygnałów o potencjalnych problemach z płynnością związaną z kryzysem wywołanym pandemią. Pomimo dobrej sytuacji, w ocenie słowackiego banku centralnego obniżenie o 0,5 p.p. (z 2,0 na 1,5\%) wskaźnika bufora ma na celu wsparcie zdolności sektora bankowego do udzielania pożyczek lokalnej gospodarce przy jednoczesnym monitorowaniu sytuacji na rynku finansowym i gotowości do dalszych obniżek wskaźnika bufora - 28.04.2020 (NBS, 2020a). Kolejne ogłoszenie - 17.07.2020 (NBS, 2020b) również skutkowało obniżeniem wskaźnika CCyB do poziomu $1,0 \%$, a następne ogłoszenia (ERRS, 2021) utrzymały ten poziom ${ }^{26}$. Ostatnie ogłoszenie (NBS, 2021) wskazuje wolę słowackiego nadzoru makroostrożnościowego do utrzymania $\mathrm{CCyB}$ na poziomie $1,0 \% \mathrm{z}$ uwagi na niewystąpienie zmian, które uzasadniałyby jego zmianę. Obniżki CCyB w 2020 r. pokryły wzrost rezerw na straty kredytowe związane z pandemią, jednak ryzyko pozostaje podwyższone i może się zmaterializować w postaci strat z tytułu ryzyka kredytowego w kolejnych okresach, zatem utrzymanie CCyB na niezmienionym poziomie $1,0 \%$ ma dać swobodę reakcji na przyszłe, niekorzystne zmiany.

Decyzja bułgarskiego banku centralnego zapadła w okresie ,,pierwszych reakcji" i w ocenie samego banku odzwierciedla radykalną zmianę środowiska w porównaniu z oceną wcześniejszego roku oraz dynamiczną sytuację zarówno w kraju, jak i za granicą ${ }^{27}$. W ramach kolejnych ogłoszeń - 23.06.2020 (BNB, 2020a), 29.09.2020 (BNB, 2020b), 17.12.2020 (BNB, 2020c) i 30.03.2021 (BNB, 2021) - utrzymano wskaźnik bufora na niezmienionym poziomie $0,5 \%$, argumentując, że tak ustalony wskaźnik CCyB przyczynić ma się do zachowania odporności systemu bankowego na ewentualne niekorzystne zmiany w otoczeniu gospodarczym, na straty z tytułu ryzyka kredytowego oraz na późniejszą presję na rentowność i pozycję kapitałową instytucji kredytowych. Bułgarski nadzór makroostrożnościowy zapowiedział w ogłoszeniu z 30.03.2021 ustalenie wskaźnika na trzeci kwartał 2021 r. w czerwcu 2021 r.

${ }^{25} \mathrm{Na}$ tamten czas wg. słowackiego nadzoru makroostrożnościowego, pozycja kapitałowa i płynnościowa banków nie ograniczała ich akcji kredytowej. Niemniej, z uwagi na potencjalny wzrost wskaźnika kredytów zagrożonych (non performing loans, NPL) po zlikwidowaniu środka pomocowego w przyszłości, jakim są wakacje kredytowe, właściwe jest zapewnienie bankom wystarczającej przestrzeni kapitałowej celem utrzymania kredytowania gospodarki, stąd ww. ogłoszenie obniżenia do poziomu $1,0 \%$.

${ }^{26} \mathrm{~W}$ ich uzasadnieniach słowacki nadzór makroostrożnościowy wskazał pewne wyważenie pomiędzy przesłankami za obniżeniem i przesłankami za zwiększeniem wskaźnika CCyB. Z jednej strony wziął pod uwagę historycznie najwyższe zadłużenie sektora prywatnego mierzone wskaźnikiem kredytów do PKB jako potencjalny sygnał do podwyższania bufora, z drugiej konieczność utrzymywania akcji kredytowej, nieznaczny spadek wskaźnika NPL i relatywnie wystarczający do tego poziom kapitałów jako prognoza do potencjalnego obniżania bufora.

${ }^{27}$ Ogłoszony w 2019 roku wzrost wskaźnika o punkt procentowy z 0,5 na $1,5 \%$ mający obowiązywać od 1 kwietnia 2020 roku anulowano, pozostawiając wskaźnik na poziomie $0,5 \%$. Dostępny w języku angielskim komunikat prasowy w tej sprawie nie dostarczał jednak informacji o potencjalnych dalszych krokach lub o motywach stojących za utrzymaniem bufora na poziomie $0,5 \%$. 


\subsection{Analiza porównawcza doświadczeń krajów EOG}

Zestawienie wybranych danych tabeli $1 \mathrm{w}$ zakresie reakcji poszczególnych krajów EOG na wybuch pandemii wirusa SARS-COV-2 w kontekście stosowania CCyB pozwala zaobserwować:

- 13 z 14 krajów (wszystkie kraje poza Luksemburgiem) obniżyło w okresie „pierwszych reakcji” częściowo bądź do zera wskaźnik obowiązującego CCyB jako manewr ostrożnościowy w kontekście antycypowanego kryzysu gospodarczego wywołanego pandemią wirusa SARS-CoV-2. Bazując na danych ERRS ${ }^{28}$ zaobserwowano, że Luksemburg dopiero w kolejnym ogłoszeniu (30.06.2020) odniósł się do wpływu pandemii na gospodarkę oraz na parametryzację narzędzi makroostrożnościowych, w tym CCyB wskazując na konieczność analizy wpływu spowolnienia gospodarczego na m.in. lukę kredytów do $\mathrm{PKB}^{29}$;

- 4 kraje z ww. 13 krajów (Bułgaria, Czechy, Słowacja, Norwegia) zdecydowały się pozostawić poziom bufora wyższy od 0\%. Kraje te, w okresie ,pierwszych reakcji" notowały ujemną standaryzowaną lukę kredytową, a w konsekwencji, nie notowały rekomendowanego, pozytywnego referencyjnego wskaźnika CCyB do związania obliczanego na podstawie standaryzowanej luki kredytowej. Dane dostępne na dzień 07.06.2021 wskazują dodatnią standaryzowaną lukę dla Norwegii $(1,85 \%)$ i Słowacji $(1,15 \%)$, jednak wartości luki nie są wystarczające, by referencyjny wskaźnik bufora antycyklicznego przekroczył wartość $0^{30}$. Metodę tę można określić mianem ostrożnościowej;

- 9 z 14 krajów w okresie ,pierwszych reakcji” całkowicie uwolniło CCyB ogłaszając go na poziomie $0 \%$ i do dnia niniejszego opracowania nie zdecydowało się na podwyższenie wysokości obowiązującego wskaźnika CCyB. Nadzory makroostrożnościowe niektórych krajów zaznaczyły, że potencjalny wzrost wskaźnika nastąpi najwcześniej:

- w trzecim kwartale 2021 r. - Szwecja (Finansinspektionen, 2021),

- w pierwszym kwartale 2022 r. - Francja (HCSF, 2021), Niemcy (BAFIN, 2021a), Irlandia (CBI, 2021), Wielka Brytania (BOE, 2021b),

- w drugim kwartale 2022 r. - Belgia (NBB, 2021);

${ }^{28}$ Luksemburski nadzór makroostrożnościowy nie opublikował, na dzień 07.06.2021, wszystkich ogłoszeń w języku angielskim, niemniej dane standaryzowane ERRS pozwalają przeanalizować pobieżnie modus operandi tamtejszego nadzoru w kontekście stosowania CCyB.

${ }^{29}$ Co warte podkreślenia, Luksemburg wylicza dodatkową lukę kredytową i to tę dodatkową lukę uwzględnia w procesie wyznaczania wysokości wskaźnika CCyB, który wynosi $0,5 \%$ niezmiennie od jego ogłoszenia (27.12.2019).

${ }^{30}$ Referencyjny wskaźnik bufora podlega interpolacji liniowej przy dolnym progu wynoszącym 2 p.p., wielkość referencyjnego wskaźnika bufora wynosi zero, gdy luka kredytów do PKB jest mniejsza lub równa dolnemu progowi (tj. 2 p.p.) zgodnie z metodologią obliczania referencyjnego wskaźnika bufora wg. Zalecenia Europejskiej Rady ds. Ryzyka Systemowego z dnia 18 czerwca 2014 r. w sprawie wytycznych dotyczących ustalania wskaźników bufora antycyklicznego (Dz.Urz. UE C 293/1 z dnia 02.09.2014). 
- 6 z ww. 9 krajów (Belgia, Dania, Islandia, Irlandia, Litwa i Wielka Brytania), które ogłosiły bufor w okresie ,pierwszych reakcji” na poziomie $0 \%$, obniżając go z wartości pozytywnych, notowało w tym okresie ujemną standaryzowaną lukę kredytową, a zatem rekomendowany (tj. referencyjny) wskaźnik również pozostawał na poziomie $0 \%$, spójnie z metodą bazylejską (tj. na podstawie standaryzowanej luki kredytowej). Notowana wcześniej - przed okresem ,pierwszych reakcji" - dla tych krajów ujemna standaryzowana luka kredytowa oraz referencyjny wskaźnik rekomendowanej wysokości bufora na poziomie $0 \%{ }^{31}$ pozwala sformułować wniosek, że kraje te stosowały ostrożnościową metodę, tj. niezerowy wskaźnik bufora ustalony w sprzyjających lub normalnych warunkach finansowych i w warunkach niezwiększonego ryzyka systemowego (mierzonych metodologią bazylejską, tj. standaryzowaną luką kredytową). Jak wynika z przywoływanych uzasadnień decyzji zawartych w standaryzowanych danych ERRS, na przykładzie banków centralnych Wielkiej Brytanii i Litwy, takie podejście (ostrożnościowa strategia zawiązywania bufora) pozwala na sukcesywne budowanie bazy kapitałów własnych banków uwzględniając opóźnienia związane z implementacją wymogu kapitałowego po ogłoszeniu jego wysokości przez organ wyznaczony (co do zasady 12 miesięcy). W dacie „ostatnich danych”, z 6 ww. krajów tylko Wielka Brytania notuje dodatnią standaryzowaną lukę kredytową i przez to dodatni referencyjny wskaźnik wysokości bufora. Biorąc pod uwagę, że Wielka Brytania jest jednym z krajów, które rozważają wzrost wskaźnika w przyszłości, a tamtejszy nadzór oczekuje, że banki wykorzystają kapitał z uwolnionego wcześniej bufora do wspierania gospodarki, można tu zaobserwować spójność (lub brak rozbieżności) pomiędzy decyzjami tamtejszego nadzoru w zakresie ustalanego wskaźnika CCyB a metodologią bazylejską;

- Pozostałe 3 z ww. 9 krajów (Francja ${ }^{32}$, Niemcy ${ }^{33}$, Szwecja ${ }^{34}$ ) to grupa krajów, które pomimo dodatniej standaryzowanej luki kredytowej, rekomendowanego dodatniego poziomu wskaźnika bufora, a nawet dodatniej dodatkowej luki

${ }^{31} \mathrm{Z}$ wyjątkiem Danii, z czerwca 2018 roku.

${ }^{32}$ Francja powołała się na Zasadę 4 Zalecenia A (Dz.Urz. UE C 293/1 z dnia 02.09.2014), w myśl której wyznaczone organy powinny szybko znieść CCyB w razie zrealizowania się ryzyka. Tamtejszy nadzór uzasadnił to szansą na złagodzenie procyklicznych zachowań instytucji kredytowych, pomagając im $\mathrm{w}$ absorpcji strat, przy jednoczesnym utrzymaniu kredytowania gospodarki i przestrzegania wymogów co do wypłacalności.

${ }^{33}$ Niemcy uzasadniając decyzje o zwolnieniu bufora pomimo dodatniej luki kredytowej podkreśliły, że luka kredytu do PKB, zarówno według metody krajowej jak i znormalizowanej, nie jest w stanie uchwycić ostatnich zmian, które nastąpiły wraz z wybuchem pandemii wirusa SARS-CoV-2 w Niemczech z powodu opóźnienia dostępnych danych. Dlatego wskaźniki te nie są wykorzystywane do decyzji o zwolnieniu bufora (BAFIN, 2021b).

${ }^{34}$ Szwecja historycznie będąc pierwszym krajem w UE decydującym się na zawiązanie bufora, utrzymywała go stale od września $2014 \mathrm{r}$. na pozytywnym poziomie, w tym na poziomie $2,5 \%$ od września 2018 roku (w większości notowań przy dodatniej standaryzowanej luce kredytowej). Aby zapewnić dobrze funkcjonującą podaż kredytu, szwedzki organ nadzoru obniża bufor antycykliczny 
kredytowej (dla Francji i Niemiec, Szwecja nie oblicza dodatkowej luki kredytowej) zdecydowały się rozwiązać w okresie „pierwszych reakcji” CCyB do poziomu $0 \%{ }^{35}$. Standaryzowana luka kredytowa po roku od okresu ,pierwszych reakcji" dla tych trzech krajów wzrosła, co przełożyło się na wzrost wskaźnika referencyjnego CCyB, który na dzień 07.06.2021 wynosił 2,5\% dla Francji i Niemiec oraz 1,7\% dla Szwecji. Na ww. dzień, kraje te nie ogłosiły wiążąco podwyżki, niemniej (patrz trzeci tiret) zakomunikowały potencjalny wzrost CCyB.

Odnosząc się natomiast do zestawienia danych tabeli 2 można zaobserwować, że:

- w przeważającej mierze (12 z 14 krajów) standaryzowana luka kredytowa odzwierciedliła negatywny trend związany ze spadkiem aktywności gospodarczej, tj. luka wzrosła przy utrzymującym się z niewielkimi wahaniami poziomie kredytu;

- wszystkie 8 krajów obliczających dodatkową lukę kredytową odnotowało dynamikę wzrostu lub spadku dodatkowej luki w tym samym kierunku co dynamikę wzrostu lub spadku standaryzowanej luki kredytowej.

\section{WNIOSKI}

Przeprowadzone badania pozwalają sformułować wniosek, że w próbie 46(6)\% krajów EOG stosujących CCyB zdają wykształcać się dwie wyraźne metody jego stosowania ${ }^{36}$ :

1. metoda reaktywna, w której zawiązanie bufora inicjuje wyraźny sygnał, np. dodatnia standaryzowana luka kredytowa lub dodatkowa luka kredytowa. Metoda ta:

- w warunkach ograniczonego ryzyka nie wiąże się z koniecznością ,zamrożenia" kapitału w ramach CCyB,

z 2,5 do $0 \%$. Celem bufora jest zwiększenie odporności banków w dobrych czasach. Bufor można następnie wykorzystać do utrzymania zdolności banków do udzielania pożyczek firmom i gospodarstwom domowym, nawet gdy gospodarka jest słabsza. Organ nadzoru w ciągu ostatnich kilku lat kilkakrotnie zwiększył wysokość bufora antycyklicznego. W porównaniu do banków w innych krajach szwedzkie banki mają obecnie duże bufory. Oznacza to, że można teraz korzystać z tych buforów w celu wsparcia zestresowanej gospodarki (Finansinspektionen, 2020).

${ }^{35}$ A contrario do grupy 4 krajów (Bułgaria, Czechy, Słowacja, Norwegia), dla których rekomendowany wskaźnik w okresie ,pierwszych reakcji” wynosił $0 \%$ a mimo to kraje te obniżyły CCyB do poziomu pozytywnego. Niezależnie od modus operandi tamtejszych nadzorów, takie działanie pozwoliło zachować część kapitału do dyspozycji w przyszłych - nieznanych w okresie „pierwszych reakcji” - warunkach.

${ }^{36}$ Na pomysł opracowania metod i strategii stosowania CCyB w kontekście skuteczności decyzji polityki makroostrożnościowej we wspieraniu podaży kredytów podczas pandemii wirusa SARS-CoV-2, niezależnie od niniejszego opracowania, wskazywał irlandzki nadzór makroostrożnościowy (CBI, 2021). 
- naraża jednak na opóźnienie pozytywnego działania CCyB względem zidentyfikowanego ryzyka systemowego z uwagi na roczny odstęp pomiędzy ogłoszeniem wskaźnika a jego faktycznym zawiązaniem w stosunku do właściwych kapitałów, co niweluje efekt „tarczy” - szczególnie w kontekście trudno przewidywalnych sygnałów;

2. metoda prewencyjna (ostrożnościowa), w której w warunkach ograniczonego ryzyka buduje się stopniowo bazę kapitałową tworząc „tarczę” dostępną do użycia również w sytuacjach systemowych o zróżnicowanej skali przewidywalności. Z drugiej strony, wiąże się ona z koniecznością „zamrożenia” kapitału w ramach CCyB na nieokreślony czas. Na podstawie wyników badań, w ramach tej metody zauważono dwa warianty:

a) wariant częściowego uwolnienia kapitału z CCyB w okresie „pierwszych reakcji” ,dzieląc” kapitał CCyB na kolejne strumienie: uwolnionej części kapitału z CCyB przeznaczonego na wsparcie zestresowanej gospodarki, dostępnego z chwilą rozwiązania CCyB; zatrzymanej części kapitału w CCyB, przeznaczonego dla dalszych działań makroostrożnościowych z użyciem CCyB, dostępnego w przyszłości z chwilą rozwiązania CCyB.

- Korzyścią tego wariantu, poza natychmiastową dostępnością obu strumieni, może być możliwość precyzyjnej alokacji zgromadzonego wcześniej kapitału w sytuacjach stresowych dla gospodarki - działania nadzorcze podejmowane w ramach kolejnych strumieni mogą być wzmocnione o doświadczenia nabyte w ramach uwolnienia wcześniejszych strumieni.

- Monitorowanie właściwych parametrów i utrzymywanie gotowości szybkiego reagowania to konieczność potencjalnej, częstszej kalibracji tych parametrów, na podstawie których ma być uwolniona zatrzymana część kapitału. Wobec tego wyzwaniem stosowania tego wariantu może okazać się zarządzanie potencjalnymi uchybieniami w gromadzeniu danych, np. co do stopnia i sposobu wykorzystania przez instytucje kredytujące wcześniej uwolnionej części kapitału, co w efekcie może nie dać adekwatnego czasowo i/lub jakościowo sygnału kiedy (oraz w jakim \%) uwolnić kolejną część kapitału;

b) wariant całkowitego uwolnienia kapitału z CCyB w okresie ,pierwszych reakcji”, czego:

- korzyścią może być natychmiastowa dostępność zgromadzonego kapitału, tj. efekt tarczy oraz mniejsze niż w wariancie częściowym obciążenie nadzorcze (brak kapitału do uwolnienia),

- z drugiej strony obciążenie nadzorcze jest większe niż w przypadku metody reaktywnej (np. uzasadnienie dla stopniowego budowania bazy kapitałowej w warunkach ograniczonego ryzyka), a ponadto

- brak korzyści z wzmocnienia o doświadczenia w ramach uwolnienia pierwszego strumienia (ryzyko nadmiernego dokapitalizowania banków, ryzyko 
dywidendy w czasie recesji np. przy niezmiennym lub malejącym poziomie akcji kredytowej z uwagi na awersję do ryzyka sektora niefinansowego).

Na podstawie analizy porównawczej niniejszego opracowania potwierdza się konstatacje przywołane w przeglądzie literatury o ograniczonej użyteczności standaryzowanej luki w świetle przeprowadzanych tam badań. Warto dodać, że w badanym okresie, tj. od 01.03.2020 do 07.06.2021, m.in. nadzory Belgii i Luksemburgu wskazywały na niską istotność ww. wskaźników w kontekście uwalniania CCyB w reżimie kryzysu gospodarczego.

\section{PODSUMOWANIE}

Pomimo ciągłej niepewności co do momentu wyjścia światowej gospodarki z recesji, na dzień 07.06.2021 da się zaobserwować przesłanki mogące sygnalizować materializującą się wolę gospodarek ku odbiciu. Wyniki badań wskazały, że spora część krajów $\mathrm{EOG}^{37}$ zapowiada stopniowe odbudowywanie bazy kapitałów CCyB. Byłyby to działania o kierunku przeciwnym dotychczasowym działaniom nadzorów, które po wybuchu pandemii koncentrowały się na utrzymywaniu niskiego lub zerowego poziomu CCyB by móc wykorzystać uwolniony kapitał contra znacznemu spowolnieniu gospodarczemu. W tym kontekście warto pozostawić - w ramach rekomendacji dalszych badań - następującą hipotezę do weryfikacji za okres kolejnego roku po okresie badanym, tj. za okres od czerwca $2021 \mathrm{r}$. do czerwca 2022 r.: notowane w drugim kwartale 2021 r. zapowiedzi stopniowego odbudowywania, od połowy $2021 \mathrm{r}$., bazy kapitałowej w ramach antycyklicznego bufora kapitałowego, które można znaleźć w raportach i danych $1 / 3$ organów nadzoru makroostrożnościowego EOG były jednymi z pierwszych wyraźnych sygnałów dochodzących od nadzoru makroostrożnościowego, zwiastujących wychodzenie gospodarek EOG z recesji.

Interesującym kierunkiem badań może okazać się również analiza konsekwencji implementacji do krajowych porządków prawnych pakietu regulacji prawa UE dotyczącego wymogów kapitałowych dla instytucji finansowych (CRD V/CRR II). Zmiany - w kontekście CCyB i na przykładzie Polski ${ }^{38}$ rozszerzają katalog parametrów, które powinien brać pod uwagę organ wyznaczony, określając wskaźnik bufora antycyklicznego, o natężenie cyklicznego ryzyka systemowego oraz adekwatność wskaźnika bufora antycyklicznego.

${ }^{37} \mathrm{~W}$ przybliżeniu $1 / 3$ wszystkich krajów EOG i ponad połowa poddanej badaniom grupy 14 krajów EOG.

${ }^{38}$ Pakiet CRD V/CRR II został implementowany do krajowego porządku prawnego Ustawą $\mathrm{z}$ dnia 25 lutego 2021 r. o zmianie ustawy - Prawo bankowe oraz niektórych innych ustaw (Dz.U. poz. 680), wchodzącą w zakresie regulacji zmieniających polskie przepisy CCyB 28 kwietnia $2021 \mathrm{r}$. 
Na dzień 07.06.2021 nie był dostępny kwartalny „Materiał na posiedzenie Komitetu Stabilności Finansowej" sporządzony w dacie po implementacji ww. pakietu prawnego. Materiał ten mógłby zawierać rekomendację KSF co do nowych parametrów CCyB i - hipotetycznie - rewizję metodologii ustalania antycyklicznego bufora kapitałowego dla Polski. Rewizję tę, niezależnie od nadchodzącej rekomendacji KSF w ramach ww. materiału, powinno podjąć się na podstawie doświadczeń krajów EOG i krajów BKNB w stosowaniu bufora w trakcie pandemii wirusa SARS-CoV-2.

\section{BIBLIOGRAFIA}

BAFIN, (2021a). Countercyclical capital buffer: BaFin does not plan to increase the buffer rate this year, https://www.bafin.de/SharedDocs/Veroeffentlichungen/EN/Meldung/2021/meldung_2021_02_26_Antizyklischer_Kapitalpuffer_en.html [dostęp 05.06.2021].

BAFIN, (2021b). Countercyclical capital buffer, https://www.bafin.de/EN/Aufsicht/BankenFinanzdienstleister/Eigenmittelanforderungen/Kapitalpuffer/antizyklischer_kapitalpuffer_artikel_en.html [dostęp 11.06.2020].

Barrel, R., Karim, D. and Macchiarelli, C. (2020). Towards an understanding of credit cycles: do all credit booms cause crises? European Journal of Finance, 26(10), pp. 978-993.

BIS, (2017). Range of Practices in Implementing the Countercyclical Capital Buffer Policy, https://www.bis.org/bcbs/publ/d407.pdf [dostęp 07.06.2021].

BNB, (2020a). Press release, https://www.bnb.bg/BankSupervision/BSCapitalBuffers/BSCBPressReleases/PR_20200623_CCB_EN [dostęp 01.06.2021].

BNB, (2020b). Press release, https://www.bnb.bg/BankSupervision/BSCapitalBuffers/BSCBPressReleases/PR_20200929_CCB_EN [01.06.2021].

BNB, (2020c). Press release, https://www.bnb.bg/BankSupervision/BSCapitalBuffers/BSCBPressReleases/PR_20201217_CCB_EN [01.06.2021].

BNB, (2021). Press release, https://www.bnb.bg/BankSupervision/BSCapitalBuffers/BSCBPressReleases/PR_20210330_CCB_EN [01.06.2021].

BOE, (2021a). Financial Stability, https://www.bankofengland.co.uk/financial-stability\#ccyb [dostęp 05.06.2021].

BOE, (2021b). Financial Policy Summary and Record of the Financial Policy Committee Meeting on 11 March 2021, https://www.bankofengland.co.uk/-/media/boe/files/financial-policy-summary-and-record/2021/march-2021.pdf [dostęp 05.06.2021].

Borio, C. (2020). The Covid-19 economic crisis: dangerously unique. Business Economics, 55, pp. 181-190.

CBI, (2021). CCyB rate announcement February 2021, https://www.centralbank.ie/docs/defaultsource/financial-system/financial-stability/macroprudential-policy/countercyclical-capitalbuffer/ccyb-rate-announcement-february-2021.pdf [dostęp 05.06.2021].

$\mathrm{CNB}$, (2020a). Statement of the Bank Board for the press conference following the monetary policy meeting, https://www.cnb.cz/en/monetary-policy/bank-board-decisions/CNB-Board-decisions-1585237680000/?tab=statement [dostęp 11.06.2020].

$\mathrm{CNB},(2020 \mathrm{~b})$. CNB leaves countercyclical capital buffer rate at $0.50 \%$, https://www.cnb.cz/en/cnb-news/press-releases/CNB-leaves-countercyclical-capital-bufferrate-at-0.50/ [dostęp 31.05.2021]. 
CNB, (2020c). CNB Board decision on financial stability, https://www.cnb.cz/en/financial-stability/cnb-board-decision/CNB-Board-decision-on-financial-stability-1606402260000/ [dostęp 31.05.2021].

$\mathrm{CNB},(2021 \mathrm{a})$. CNB leaves countercyclical capital buffer rate at $0.50 \%$, https://www.cnb.cz/en/cnbnews/press-releases/CNB-leaves-countercyclical-capital-buffer-rate-at-0-00001.50/ [dostęp 31.05.2021].

CNB, (2021b). Provision of a general nature II/2021, https://www.cnb.cz/en/financial-stability/macroprudential-policy/the-countercyclical-capital-buffer/provision-of-a-general-natureon-setting-the-countercyclical-capital-buffer-rate/Provision-of-a-general-nature-II-2021/ [dostęp 30.05.2021].

Deryugina, E., Ponomarenko, A. and Rozhkova, A. (2020). When are credit gap estimates reliable? Economic Analysis and Policy, 67.

Dobrzańska, A. (2020). Polityka makroostrożnościowa w czasie pandemii. Bezpieczny Bank, 4(81), ss. 136.

Dobrzańska, A. i Kurowski, Ł. (2019). CCyB jako instrument polityki makroostrożnościowej. Dotychczasowe doświadczenia w UE. Bezpieczny Bank, 1(74), ss. 8-42.

Dyrektywa Parlamentu Europejskiego i Rady (UE) 2019/878 z dnia 20 maja 2019 r. zmieniającą dyrektywę 2013/36/UE w odniesieniu do podmiotów zwolnionych, finansowych spółek holdingowych, finansowych spółek holdingowych o działalności mieszanej, wynagrodzeń, środków i uprawnień nadzorczych oraz środków ochrony kapitału, Dz.Urz. UE L 150 z dnia 07.06.2019, s. 253, z późn. zm.

ERRS, (2017). Financial Stability Implications of IFRS 9, https://www.esrb.europa.eu/pub/pdf/reports/20170717_fin_stab_imp_IFRS_9.en.pdf [dostęp 07.06.2021].

ERRS, (2021). Countercyclical capital buffer, https://www.esrb.europa.eu/national_policy/ccb/shared/data/esrb.ccybd_CCyB_data.xlsx [dostęp 07.06.2021].

Finansinspektionen, (2020). FI lowers the countercyclical capital buffer to zero, https://www.fi.se/en/published/press-releases/2020/fi-lowers-the-countercyclical-capitalbuffer-to-zero/ [dostęp 11.06.2020].

Finansinspektionen, (2021). Countercyclical buffer rate, https://www.fi.se/contentassets/2813f977246d4fa8b861d5e2c7a931a9/kontracykliskt-buffertv-buffertriktv-kv12021eng.pdf [dostęp 05.06.2021].

Galan, J.E. and Mencia, J., (2021). Model-based indicators for the identification of cyclical systemic risk. Empirical Economics.

Giese, J., Andersen, H., Bush, O., Castro, C., Farag, M. and Kapadia, S., (2014). The credit-to-GDP gap and complementary indicators for macroprudential policy: Evidence from the UK. International Journal of Finance and Economics, 19(1), pp. 25-47.

HCSF, (2021). Press Release, https://www.economie.gouv.fr/files/files/directions_services/hcsf/HCSF_20210318_CP_ENG.pdf [dostęp 05.06.2021].

NBB, (2021). Quarterly decision of the National Bank of Belgium on the countercyclical buffer rate for 2021Q2: 0\%, https://www.nbb.be/doc/cp/eng/2021/20210331_bufferrate_2021q2.pdf [dostęp 05.06.2021].

NBS, (2020a). Quarterly Commentary on Macroprudential Policy April 2020, https://www.nbs.sk/_img/Documents/_Dohlad/Makropolitika/WEB_Stvrtrocny_komentar_2020_April-TRA-EN.pdf [dostęp 10.06.2020].

NBS, (2020b). Quarterly Commentary on Macroprudential Policy July 2020, https://www.nbs.sk/_img/Documents/_Dohlad/Makropolitika/WEB_Stvrtrocny_komentar_2020_July-TRA-EN.pdf [dostęp 31.05.2020].

NBS, (2021). Macroprudential Commentary March 2021, https://www.nbs.sk/_img/Documents/_Dohlad/Makropolitika/WEB_Makroprudencialny_komentar_2021_April-TRAEN.pdf [dostęp 31.05.2021]. 
Pfeifer, L. and Hodula, M., (2021). A profit-to-provisioning approach to setting the countercyclical capital buffer. Economic Systems, 45(1).

Porozumienie o EOG, Dz.Urz. UE. L. z 1994 r., nr 1, s. 3 z późn. zm.

Pyka, I., Zygierewicz, M., Bolibok, P. i Nocoń, A. (2019). Polityka makroostrożnościowa w regulowaniu stabilności sektora bankowego. Katowice: Wydawnictwo Uniwersytetu Ekonomicznego w Katowicach.

Regjeringen, (2020a). Reduction of the countercyclical buffer, https://www.regjeringen.no/en/aktuelt/reduction-of-the-countercyclical-buffer/id2693388/ [dostęp 11.06.2020].

Regjeringen, (2020b). Countercyclical buffer unchanged, https://www.regjeringen.no/en/aktuelt/countercyclical-buffer-unchanged/id2714522/ [dostep 30.05.2021].

Regjeringen, (2020c). Countercyclical buffer unchanged, https://www.regjeringen.no/en/aktuelt/countercyclical-buffer-unchanged2/id2765822/ [dostęp 30.05.2021].

Regjeringen, (2020d). Countercyclical buffer unchanged, https://www.regjeringen.no/en/aktuelt/countercyclical-buffer-unchanged3/id2814810/ [dostęp 30.05.2021].

Regjeringen, (2021). Countercyclical buffer unchanged Q1 2021, https://www.regjeringen.no/en/aktuelt/countercyclical-buffer-unchanged-q1-2021/id2839216/ [dostęp 30.05.2021].

Reigl, N. and Uusküla, L. (2021). Alternative frameworks for measuring credit gaps and setting countercyclical capital buffers. Journal of Financial Economic Policy, 13(2), pp. 161-179.

Rizwan, M.S., Ahmad, G. and Ashraf, D. (2020). Systemic risk: The impact of COVID-19. Finance Research Letters, 36.

Rozporządzenie Parlamentu Europejskiego i Rady (UE) 2019/876 z dnia 20 maja 2019 r. zmieniające rozporządzenie (UE) nr 575/2013 w odniesieniu do wskaźnika dźwigni, wskaźnika stabilnego finansowania netto, wymogów w zakresie funduszy własnych i zobowiązań kwalifikowalnych, ryzyka kredytowego kontrahenta, ryzyka rynkowego, ekspozycji wobec kontrahentów centralnych, ekspozycji wobec przedsiębiorstw zbiorowego inwestowania, dużych ekspozycji, wymogów dotyczących sprawozdawczości i ujawniania informacji, a także rozporządzenie (UE) nr 648/2012, Dz.Urz. UE L 150 z dnia 07.06.2019, s. 1, z późn. zm.

Rubio, M. and Carrasco-Gallego J.A. (2016). The new financial regulation in Basel III and monetary policy: A macroprudential approach. Journal of Financial Stability, 26, pp. 294-305.

Rubio, M. and Yao, F. (2020). Bank capital, financial stability and Basel regulation in a low interestrate environment. International Review of Economics \& Finance, 67, pp. 378-392.

Solarz, J.K. i Waliszewski, K. (2020). Całościowe zarządzanie ryzykiem systemowym. Pandemia COVID-19. Kraków: Wydawnictwo edu-Libri.

Traktat ustanawiający Europejską Wspólnotę Gospodarczą, Dz.U. 2004, nr 90, poz. 864/2 z późn. zm.

Umowa o wystąpieniu Zjednoczonego Królestwa Wielkiej Brytanii i Irlandii Północnej z UE i Europejskiej Wspólnoty Energii Atomowej, Dz.U. UE. C. z 2019 r., s. 144.

Ustawa z dnia 25 lutego 2021 r. o zmianie ustawy - Prawo bankowe oraz niektórych innych ustaw, Dz.U. 2021, poz. 680.

Zalecenie Europejskiej Rady ds. Ryzyka Systemowego z dnia 18 czerwca 2014 r. w sprawie wytycznych dotyczących ustalania wskaźników bufora antycyklicznego, Dz.Urz. UE C 293/1 z dnia 02.09.2014. 